\title{
HOW DOES THE USE OF DERIVATIVES AFFECT FIRMS' FINANCIAL PERFORMANCE IN TURKISH NON-LIFE INSURANCE INDUSTRY?
}

\author{
TÜREV ENSTRÜMAN KULLANIMI TÜRKİYE HAYAT DIŞI \\ SIGGORTA SEKTÖRÜNDE YER ALAN FİRMALARIN FINANSAL \\ PERFORMANSINI NASIL ETKILLEMEKTEDİR?
}

\author{
Burak ALAN ${ }^{*}$ (6) \\ Aslı AYBARS ${ }^{* *}$
}

\begin{abstract}
Hedging risk is the major reason why derivative instruments have been developed in the 1840s. However, due to the ever-changing conditions in the financial markets, these instruments have further been used for speculative purposes and arbitrage opportunities. Nevertheless, this paper focuses on the influence of derivative usage for hedging purposes on the profitability of firms in the Turkish nonlife insurance industry. The data consists of 25 non-life insurance companies operating in Turkey from 2009 to 2019, inclusive. The findings based on panel data analysis reveal that derivative usage contributes to the firms' financial performance measured by return on assets (ROA) in that firms that use derivatives demonstrate a 5\% higher ROA figure in comparison to non-users.

Keywords: Derivative Usage, Financial Performance, Insurance Industry, Panel Data Analysis

JEL Classification: C23, L25, G23

$\ddot{\mathbf{O z}}$

Riskten korunma, türev araçların 1840’larda geliştirilmesinin temel nedenidir. Ancak, finansal piyasalardaki sürekli değişen koşullar nedeniyle, bu enstrümanlar spekülatif amaçlar ve arbitraj fırsatları için de kullanılmaya başlamıştır. Bununla birlikte, bu makale riskten korunma amaçlı türev entrüman kullanımının Türkiye’de hayat dışı sigorta sektöründe faaliyet gösteren firmaların karlılığı üzerindeki etkisine odaklanmaktadır. Veri seti, 2009'dan 2019'a kadar Türkiye'de faaliyet gösteren 25 hayat dışı sigorta şirketinden oluşmaktadır. Panel veri analizine dayalı bulgular, türev kullanımının firmaların ROA ile ölçülen finansal performansına katkıda bulunduğunu ortaya koymaktadır. Türev ürünleri kullanan firmaların, kullanmayan firmalara kıyasla \%5 daha yüksek ROA’ya sahip olduğu ortaya çıkmaktadır.
\end{abstract}

Anahtar Kelimeler: Türev Kullanımı, Finansal Performans, Sigorta Sektörü, Panel Data Analizi JEL Sınıflandırması: C23, L25, G23

* Marmara University, Faculty of Business Administration, PhD Candidate, E-mail: burak.alan@marun.edu.tr

** Marmara University, Faculty of Business Administration, E-mail: asli.aybars@marmara.edu.tr 


\section{Introduction}

Option pricing and hedging appear to have developed in a series of steps in the 1970s. It is known from historical references that market-neutral delta hedging, put-call-parity, hedging options with options, and other statistical option pricing models were known by the early 1900s and yet to be further investigated and extended (Haug, 2009). More than one hundred years earlier, Bachelier (1900) and Bronzin (1908) released option-pricing models that were very similar to those that are being used today.

There is a long tradition of derivative usage than one would ever expect. The first transactions, which might fit into the concept of a derivative, could date back before the Common Period. As early as the Bible, examples of exchanging private labor for future payments, which may be called a type of futures contract, can be found (Chance, 1998).

Around a hundred thousand years ago, trade was an established activity among primitive people, who traded goods and services before the advent of currency. Non-perishable items such as wine, grain or other things were used by citizens as an intermediate store of value. The people of Sumer began to write and use mathematics to create a ground-breaking new financial transaction accounting system between 4500 and 4000 BCE. To reflect commodities, the Sumerians used clay tokens kept in a clay jar and later clay writing tablets, documenting arrival dates for items being exchanged. These arrangements resembled futures contracts and are considered to be the first examples of financial derivatives. The first recorded example of a derivative exchange in ancient Greece dates back to about 600 BCE when the philosopher Thales of Miletus became the world's first dealer of oil derivatives, that is, olive oil (Weisenthal, 2012).

An example of a derivative instrument, which is close to how and why we use them today, was firstly created regarding commodity trading. In 1848, the Chicago Board of Trade opened. During the harvest season, farmers used Chicago's central position as a storage area and marketplace for grain. As the crop was seasonal, grain prices oscillated with the season. Farmers were searching for a way to stabilize prices and so formed a "to-arrive" deal. These early derivatives were used by farmers as a tool to lock in the price of grain at which the crops could be traded and; thus, prevent dramatic fluctuations. With supervision from the Board of Trade, these contracts were sold and would gradually become uniform contracts by 1865 (Chance, 1998). The Chicago markets were home to trade in a variety of commodity types in the Twentieth Century, from agricultural goods to metals. With the invention of the machine came the next chapter of the tale of derivatives. The way derivatives were generated and traded had been revolutionized. Humans have often found ways to establish relationships and exchanged items with each other, regardless of the challenges. Clay vessels, laptops, equal letters, rice vouchers, and microprocessors were once modern inventions for our ancestors that revolutionized life and industry just as fin-tech is now implementing a new wave of innovations that aim to optimize the way business is conducted by counterparties.

Derivatives, as known today, are financial securities with values derived from other properties, for example from shares, international currencies or bonds. Derivatives are often used to hedge 
a stake or to bet (to defend against the possibility of reverse movement in an asset) on potential changes in the underlying instrument. To hedge stocks and even entire portfolios, hedging is a popular method of risk control in the equity market, where investors use derivatives such as futures, forwards, and options.

Derivatives were identified memorably by Warren Buffett as "financial weapons of mass destruction". The much-celebrated financial goods in the mainstream press have become a dirty word. Without them, though, capital markets of individual countries and the global financial markets as a whole certainly will not function properly. Markets, companies, governments, and supranational corporations rely on these tools, which are often simple but sometimes extraordinarily complicated, to hedge risk and take advantage of opportunities.

Owing to the magnitude of some financial success stories without relying on these innovative instruments in this area of the economy, derivatives have lately acquired a new sense of disgrace. However, not all companies use these advanced techniques very much. For the past few decades, these methods have proved to be extremely effective, yet volatile instruments. These techniques, on the other hand, have an outstanding record of effectiveness in reducing risks.

The objective of this article is to find the impact of hedging on the financial performance of Turkish non-life insurance firms by using derivative instruments, which is a field that has been examined in the literature in only a relatively limited way. As far as the literature review is concerned, no prior study has been performed for the Turkish insurance industry concerning the use of derivatives and associated financial performance indicators. Therefore, the article contributes to the established array of literature with respect to derivative instruments. In summary, the article attempts to distinguish the financial performance of the firms that use derivative instruments for hedging purposes from those which do not for the non-life insurance companies operating in Turkey.

This article continues as follows: The next section includes a literature review. The data, methodology, and explanations as to variables are provided in Section 3. Empirical findings are presented in Section 4. Lastly, the article concludes with Section 5.

\section{Literature Review}

The research literature is very limited concerning the use of derivatives in the insurance market in particular. The proof is available in the US only with the works of Colquitt and Hoyt (1997), Cummins et al. (1997), and Cummins et al. (2001) and in the UK with that of Hardwick and Adams (1999) that tracks derivative hedging activities in the insurance sector. Given the importance of risk management as a global problem for the banking and insurance markets, this shortfall in academic works must be resolved. Besides, Cummins et al. (1997) contend that the determinants of hedging behavior vary, for example, between general and life insurers, across 
various sub-sectors of the industry. To the best knowledge of the authors, no prior article has studied the nexus between financial performance and hedging in the Turkish insurance industry.

A variety of potential relations between the tendency of a business to use derivatives and its incentives has been recorded in previous studies. Colquitt and Hoyt (1997), Cummins et al. (1997), Cummins et al. (2001), and De Ceuster et al. (2003) claim that owing to economies of scale, bigger insurers are more likely to participate in derivative practices. Moreover, Yang et al. (2001) claim that bigger firms are more likely to use swaps than smaller ones. Cummins et al. (1997) find that the proportion of assets held in stocks is positively related to the presence of derivatives. In comparison, because their size and timing of future claim expenses remain unpredictable, non-life insurance businesses are largely more vulnerable to liquidity risk than their life peers are. For insurers with more stable reserves, the need to handle liquidity risk by derivative trades may be somewhat reduced.

Colquitt and Hoyt (1997) provide proof of the positive relationship between the likelihood of derivatives being used and the magnitude of the mismatch between the asset and the length of the responsibility. It is predicted that the greater the mismatch of an insurer, the more likely it is to use derivatives. Furthermore, to stabilize earnings and offer safeguards from catastrophic damages, non-life insurance businesses typically carry out reinsurance cover. Reinsurance can be regarded as a replacement for derivatives from the viewpoint of risk management. A negative association between reinsurance dependency and engagement in derivatives is known (De Ceuster et al., 2003). The estimated impact of the company's reinsurance dependency on the company's use of derivatives is also negative. Insurers with weaker underwriting performance and fewer business lines are at risk of unforeseeable operating results. Consequently, to hedge their future risks, they will require derivatives. Since stock funds are more likely than cooperative firms to be active in riskier industries, derivatives are more likely to be used by them.

Hardwick and Adams (1999) together with Shiu (2007) demonstrate that joint business administrators tend to be less inclined to participate in volatile operations and are; thus, more likely to use options to offset risks than their equity company peers.

In the "complementarity" principle, the dispute is that insurance companies, which are likely to participate in risk managing practices, would prefer to employ all hedging methods, whereas the "substitution" concept assumes an undesirable association between reinsurance and derivatives, with the reason being that businesses take an overall risk management strategy. If insurance companies use derivatives to minimize their exposure to the risk of investment, they are in a position to expect a higher underwriting risk.

The finance literature reveals that hedging with derivatives increases the debt potential of a business (Bartram et al., 2009; Graham and Roger, 2002). Therefore, in a related manner, it would be expected that insurers with worse financial results would use derivatives. As stated in the work of Fauver and Naranjo (2010), the link between derivative usage and firm value is negative in firms with greater agency and monitoring problems. Furthermore, insurers with poor results, in 
particular those which may be engaged in ventures with high estimated investment losses, may, for hedging purposes, participate in derivative contracts and; thereby, be able to monitor the opportunity for underinvestment. Contrarily, insurers typically use derivatives for risk-reducing purposes; those with poor results would prefer to use fewer derivatives and; therefore, assume more risk for higher returns on their own (Shiu, 2020). Furthermore, if hedging techniques for derivatives operate successfully, hedging companies should have improved operational and financial efficacy, which should be reflected in their financial performance. In a large-scale survey analyzing derivatives owned by 7319 companies in 50 countries representing about 80 percent of non-financial companies' global market capitalization, Bartram et al. (2009) observed that hedgers appear to be bigger and more lucrative in value, having a higher ROA.

Choi et al. (2013) examine the financial and operational hedging activities of US pharmaceutical and biotech firms during 2001-2006 and find that using financial derivatives impacts financial performance, hence increases the value of a company. Similar evidence is put forth by Chanzu and Gekara (2014), who conduct a content analysis based on survey answers and found a positive impact of derivative usage on the financial performance of 11 listed companies in the Nairobi Securities Exchange. Furthermore, Lau (2016) suggest that the use of derivatives leads to higher ROA and ROE, which are key drivers of a company's market value in Malaysia. Contrarily, Shiu (2020) utilize data belonging to UK non-life insurance companies during 1994-2011 just to find that there is no significant relation between derivative usage and financial performance. Said (2011) analyzed the correlation of derivative usage and financial performance in the banking sector in the US with the period from 2002 to 2009 and suggested that there was a positive correlation between bank performance and efficiency with the derivative usage. As can be seen most of the prior studies in literature document a positive association between derivatives usage; therefore, the hypothesis of this study can be formed as follows:

H1: The financial performance of derivative users is higher than the performance of non-users.

\section{Data and Methodology}

\section{I. Data}

Data is retrieved from Insurance Association of Turkey's (IAT) official website. This dataset comprises returns for Turkish non-life insurance companies during the years between 2009 and 2019 , inclusive. The major reason why this time span is chosen rests on the aim to exclude the impact of the financial crisis in 2008 together with data availability issues.

The dataset excludes insurance companies that are reporting negative premiums in any of the five core lines of business; namely, health, casco, fire, general liabilities, and motor third party liability. The observations with outliers at the $0.5 \%$ and $99.5 \%$ levels are removed from the initial dataset to achieve consistency in the final sample. Accordingly, the analysis rests upon 25 insurers during the 2009-2019 period, making a total of 275 firm-year observations. For the period analysed, 105 of the 
275 observations (38.2\%) in the sample are found to have participated in the derivatives market. As can be seen by this finding, derivatives usage is not widespread in the Turkish non-life sector.

\subsection{Model and Methodology}

Panel data regression with a strongly balanced data set is utilized in this study to investigate the impact of hedging with derivatives on financial performance in the Turkish non-life insurance industry. After testing the model with the Likelihood-ratio test (Buse, 1982), the model is determined to be a classical model.

The model can be established as in the following formula;

$$
R O A_{i, t}=f\left(D E V_{i, t}, O E V_{i, t}\right)+\varepsilon_{i, t}
$$

where the subscript i represents the insurer; $t$ denotes the year; ROA is the ratio of net profit to the total assets in a given insurer-year; DEV is the dummy variable that takes on the value of 1 or 0 depending on whether firm $i$ at time $t$ uses derivatives or not, respectively; OEV represents the explanatory variables. Table 1 below shows all variables; namely, dependent, independent, and control variables together with their abbreviations and explanations.

Table I: Variable Descriptions

\begin{tabular}{|c|c|c|}
\hline Variable Name & Abbreviation & Explanation \\
\hline Return on Asset & ROA & The ratio of net profit to total assets. \\
\hline Derivative Participation & DEV & Derivatives nonusers $=0$, derivatives users $=1$ \\
\hline Equity to Asset Ratio & EQT & The ratio of total equity to total assets. \\
\hline Liquidity Ratio & LIQ & The ratio of liquid assets to total assets. \\
\hline Net Loss Ratio & NLR & The ratio of total net incurred loss to net earned premium. \\
\hline Financial Profit Margin & FPP & $\begin{array}{l}\text { It is the ratio of financial profit divided by gross written } \\
\text { premiums }\end{array}$ \\
\hline Insurance Leverage & INL & The ratio of gross written premiums to surplus. \\
\hline $\begin{array}{l}\text { Mismatch of Long Term } \\
\text { Assets }\end{array}$ & MISASS & $\begin{array}{l}\text { The ratio of the difference between other than long-term } \\
\text { admissible assets and liabilities to total admissible assets } \\
\text { (only if a positive value is found, otherwise MISLIAB) }\end{array}$ \\
\hline $\begin{array}{l}\text { Mismatch of Long Term } \\
\text { Liabilities }\end{array}$ & MISLIAB & $\begin{array}{l}\text { The ratio of the difference between other than long-term } \\
\text { liabilities and admissible assets to total admissible assets } \\
\text { (only if a positive value is found, otherwise MISASS) }\end{array}$ \\
\hline Business-Mix & $\begin{array}{l}\text { HLT, CAS, FIRE, } \\
\text { GLI, MTPL }\end{array}$ & $\begin{array}{l}\text { The proportions of gross written premiums in each of the } \\
\text { five lines of business, involving of health, casco, fire, general } \\
\text { liabilities, and motor third party liability. }\end{array}$ \\
\hline
\end{tabular}


Based on the results of the Likelihood-ratio (LR) Test, no time or unit effect is included in the model and, accordingly, the classical panel data model is found to fit the study's dataset. Heteroscedasticity can occur because the results originate from a wide number of crosssectional insurance companies; therefore, the White heteroscedasticity-consistent estimators should be reported on the condition that the dataset is heteroskedastic (White, 1980). The result of the Breusch-Pagan/Cook-Weisberg test reveals the presence of heteroskedasticity. To test for autocorrelation, the Wooldridge test is performed with the finding that there is no sign of autocorrelation. Accordingly, the model is estimated as a classical model with robust standard errors (Tatoğlu, 2020).

Shapiro and Wilk (1965) normality test has been done after testing for heteroskedasticity and autocorrelation. The test results suggests that all the variables used in the analysis are not normally distributed. Therefore, outliers have been removed from the data as stated above.

The summary statistics for all the variables used in the complete sample of the study are provided in Table 2, where ROA is observed to have a mean of - 0.0239 and a standard deviation of 0.1303. Involvement in derivatives is observed in 105 insurer-year observations accounting for $38.2 \%$ of the overall sample.

Table 2: Summary Statistics

\begin{tabular}{lllll}
\hline Variables & Mean & St. Dev. & Minimum & Maximum \\
\hline ROA & -0.0239 & 0.1303 & -1.17 & 0.15 \\
EQT & 0.2695 & 0.1448 & -0.54 & 0.92 \\
LIQ & 0.6084 & 0.1497 & 0.17 & 1.08 \\
NLR & 0.7426 & 0.2907 & -0.52 & 2.67 \\
FPP & -0.0003 & 0.2006 & -2.57 & 1.07 \\
INL & 1.1209 & 0.9364 & -1.17 & 0.15 \\
MISASS & 0.0513 & 0.0825 & 0 & 0.44 \\
MISLIAB & 0.0244 & 0.0806 & 0 & 0.58 \\
HLT & 0.0573 & 0.0723 & 0 & 0.44 \\
CAS & 0.2038 & 0.1263 & 0 & 0.62 \\
FIRE & 0.1658 & 0.1016 & 0 & 0.68 \\
GLI & 0.1031 & 0.0951 & 0 & 0.78 \\
MTPL & 0.2367 & 0.1848 & 0 & 0.89 \\
\hline & & & & \\
Variables & Coding & Frequency & of Sample & \\
\hline DEV & 1 & 105 & 0.3818 & \\
\cline { 2 - 4 } & 0 & 170 & 0.6182 & \\
\hline
\end{tabular}


Table 3 displays the Pearson correlation matrix with dependent and independent variables. Derivative participation and ROA are positively correlated at a $1 \%$ significance level. Derivative usage is also positively correlated with health concentration at a $1 \%$ significance level and negatively correlated with general liability concentration at a 5\% significance level. There are no significantly high correlations among independent variables with no more than a $60 \%$ correlation level.

Table 3: Correlation Matrix

\begin{tabular}{|c|c|c|c|c|c|c|c|c|c|c|c|c|}
\hline & DEV & EQT & LIQ & NLR & FPP & INL & MISASS & MISLIAB & HLT & CAS & FIRE & GLI \\
\hline EQT & -0.02 & 1 & & & & & & & & & & \\
\hline LIQ & 0.09 & $\begin{array}{l}0.15 \\
* *\end{array}$ & 1 & & & & & & & & & \\
\hline NLR & -0.06 & $\begin{array}{l}-0.43 \\
* * *\end{array}$ & -0.07 & 1 & & & & & & & & \\
\hline FPP & 0.02 & $\begin{array}{l}-0.15 \\
* *\end{array}$ & -0.09 & $\begin{array}{l}0.10 \\
*\end{array}$ & 1 & & & & & & & \\
\hline INL & 0.01 & $\begin{array}{l}-0.60 \\
* * *\end{array}$ & -0.06 & $\begin{array}{l}0.32 \\
* * *\end{array}$ & $\begin{array}{l}0.29 \\
* * *\end{array}$ & 1 & & & & & & \\
\hline MISASS & 0.03 & 0.18 & $\begin{array}{l}-0.52 \\
* * *\end{array}$ & $\begin{array}{l}0.12 \\
* *\end{array}$ & -0.06 & -0.02 & 1 & & & & & \\
\hline MISLIAB & -0.05 & 0.04 & $\begin{array}{l}0.12 \\
*\end{array}$ & -0.06 & $\begin{array}{l}0.13 \\
* *\end{array}$ & 0.09 & $\begin{array}{l}-0.19 \\
\star * *\end{array}$ & 1 & & & & \\
\hline HLT & $\begin{array}{l}0.23 \\
* * *\end{array}$ & 0.09 & 0.00 & 0.05 & -0.01 & -0.06 & $\begin{array}{l}0.28 \\
* * *\end{array}$ & $\begin{array}{l}-0.23 \\
* * *\end{array}$ & 1 & & & \\
\hline CAS & -0.01 & -0.07 & $\begin{array}{l}-0.14 \\
* *\end{array}$ & $\begin{array}{l}0.27 \\
* * *\end{array}$ & $\begin{array}{l}-0.17 \\
* * *\end{array}$ & 0.02 & $\begin{array}{l}0.21 \\
* * *\end{array}$ & $\begin{array}{l}-0.42 \\
* * *\end{array}$ & 0.08 & 1 & & \\
\hline FIRE & -0.03 & 0.02 & -0.08 & $\begin{array}{l}-0.12 \\
* *\end{array}$ & $\begin{array}{l}-0.12 \\
*\end{array}$ & 0.01 & 0.02 & $\begin{array}{l}-0.40 \\
* * *\end{array}$ & -0.05 & $\begin{array}{l}0.23 \\
* * *\end{array}$ & 1 & \\
\hline GLI & $\begin{array}{l}-0.13 \\
* *\end{array}$ & $\begin{array}{l}0.10 \\
*\end{array}$ & $\begin{array}{l}-0.11 \\
*\end{array}$ & $\begin{array}{l}-0.16 \\
* * *\end{array}$ & 0.02 & 0.03 & $\begin{array}{l}0.11 \\
*\end{array}$ & 0.00 & 0.00 & -0.05 & $\begin{array}{l}0.20 \\
* * *\end{array}$ & 1 \\
\hline MTPL & -0.08 & $\begin{array}{l}-0.33 \\
* * *\end{array}$ & $\begin{array}{l}0.17 \\
* * *\end{array}$ & $\begin{array}{l}0.26 \\
* * *\end{array}$ & $\begin{array}{l}-0.11 \\
*\end{array}$ & -0.05 & -0.01 & $\begin{array}{l}-0.33 \\
* * *\end{array}$ & 0.08 & $\begin{array}{l}0.17 \\
* * *\end{array}$ & $\begin{array}{l}-0.17 \\
* * *\end{array}$ & $\begin{array}{l}-0.32 \\
*\end{array}$ \\
\hline
\end{tabular}

Note: ${ }^{* * *}$ indicates statistical significance at the $1 \%$ level; ${ }^{* *}$ indicates statistical significance at the $5 \%$ level; and ${ }^{*}$ indicates statistical significance at the $10 \%$ level.

\section{Empirical Results}

Table 4 below shows the results of the regression analysis. The probability of the F-test of the model suggests that the model is meaningful, and $59.4 \%$ of the change in the dependent variable can be explained by the variables selected as denoted by the R-squared value. Most of the explanatory 
variables, alongside with DEV variable, turn out to be significant and consistent with the prior works in the literature.

The use of derivatives is significant, at 0.01 significance level, and positively linked with ROA as displayed in the table. The approximate coefficient of 0.0523 shows that the use of derivatives contributed favorably to ROA with a $5 \%$ higher value on behalf of derivative users on average. This outcome is largely consistent with other previous researches which suggest that users of derivatives have a higher ROA in comparison to non-users (for instance, see Allayannis et al., 2012; Bartram et al., 2009; Brown et al., 2006; Choi et al., 2013; Lau, 2016).

Table 4: Regression Results on Performance

\begin{tabular}{lccc}
\hline Independent Variables & Expected Sign & Coefficient & Standard Deviation \\
\hline DEV & + & $0.0523^{* * *}$ & 0.0088 \\
EQT & + & $0.4858^{* * *}$ & 0.1602 \\
LIQ & - & -0.0142 & 0.0474 \\
NLR & - & $-0.1674^{* * *}$ & 0.0358 \\
FPP & + & $0.1257^{* * *}$ & 0.0362 \\
INL & + & 0.0298 & 0.0195 \\
MISASS & & $-0.2097^{* * *}$ & 0.0650 \\
MISLIAB & & 0.0560 & 0.0907 \\
HLT & & $0.3962^{* * *}$ & 0.0695 \\
CAS & -0.1056 & 0.0703 \\
FIRE & 0.0735 & 0.0743 \\
GLI & $0.2672^{* * *}$ & 0.0929 \\
MTPL & $0.1677^{* * *}$ & 0.0326 \\
Constant & -0.1362 & 0.0924 \\
\hline & & \\
\hline Number of observations & & \\
R-squared & & 275 & \\
F value (p-value) & $59.4 \%$ & \\
\hline N & & 0.0000 & \\
\hline
\end{tabular}

Note: ${ }^{* *}$ shows significance at the $1 \%$ level; ${ }^{* *}$ shows significance at the $5 \%$ level; and ${ }^{*}$ shows significance at the $10 \%$ level.

Larger businesses can usually work more effectively than smaller organizations relying on the principle of 'economies of scale' since they gain competitive benefits in terms of both variable and fixed costs. A favorable association between insurance company size and risk-adjusted ROA (Ma and Elango, 2008; Elango et al., 2008) or basic ROA has been reported in previous studies (Lee and Lee, 2012). Therefore, larger insurers are expected to do better than their smaller local rivals. EQT shows the insurer company's size scaled down to its total assets. The results suggest a highly 
significant (1\% level) positive relationship between the size of the company and its financial performance, which is ROA in this study.

In general, insurers who spend more of their premiums on liquid assets see lower yields on equity than insurance companies without liquid assets. Thus, a negative association between the liquidity of the insurer and financial results is expected. The findings of the study demonstrate a negative relationship though not significant.

Insurers' underwriting outcomes specifically influence their financial performance. It is expected to find that insurers have improved net financial performance and better underwriting performance. In the results, NLR is negative and significant at a $1 \%$ level, which is consistent with Shiu (2020).

FPP is the indicator of the company's financial performance in the insurance industry and it is expected to have a positive relationship with the company's overall performance. As the result suggests, there is a positive and significant relationship at the $1 \%$ level with ROA.

The MISASS variable, which indicates how much long-term assets outweigh long-liabilities, is significant at the $1 \%$ level and negative, indicating that this mismatch reduces the financial performance of the non-life insurance companies. In other words, when there is a mismatch between long-term assets and long-term liabilities in favor of assets, the financial performance is negatively affected.

Naturally, the insurer's investment portfolio would be an indicator for the essence of the insurer's product portfolio, with all investments ultimately deciding the insurer's overall output. Therefore, the potential effect of business lines on risk-adjusted ROA (Elango et al., 2008) was considered. Cummins et al. (2001) found that insurers using derivatives hedged the risk from their loss portfolio. To hedge their interest and FX rate costs, insurers can also need to use derivatives. According to the results shown in the table above, the companies that concentrated on health, general liabilities, and motor third party liability have better ROA. The relation is positive and significant at $1 \%$ level, while casco and fire business concentration is not significant.

\section{Conclusion}

Derivatives have been an important component of all economic structures in today's economy. Any major business can use derivatives to hedge against uncertainties, in particular those related to international risk. The bulk of these undertakings use these arrangements to protect against the danger of energy inflation, currency risk or lower borrowing rates. These are the threats that companies face organically apart from the risks that are generated by financial transactions.

In today's market, the use of derivatives has changed from the original explanation of why the instruments were initially developed. Although it is still common to use derivatives for hedging purposes, new applications for these techniques have become widespread. The essence of the 
adjustment in the derivative contract is explained by the use of betting and arbitrage. However, in terms of derivatives, the application of these strategies is not limited to the financial industry.

The influence of derivative usage on the profitability of Turkish insurance firms is empirically examined in this paper. The findings reveal that derivative usage has a positive impact on ROA, suggesting that the use of derivatives contribute favorably to an increased ROA between users and non-users in that 5\% higher ROA on average is observed in the Turkish non-life insurance companies' profitability. Forthcoming studies can be performed for longer time spans. Furthermore, cross-country analyses can be conducted for the insurance industry to be able to generalize the results in this array of literature.

\section{Acknowledgments}

I would like to take a moment to appreciate my beloved Associate Professor Asl1 Aybars for her insights and positive energy.

\section{References}

Allayannis, G., Lel, U., and Miller, D. (2012). The use of foreign currency derivatives, corporate governance, and firm value around the world. Journal of International Economics, 65-79.

Bachelier, L. (1900). Théorie de la spéculation. Annales scientifiques de l'É.N.S, 21-86.

Bartram, S., Brown, G., and Fehle, F. (2009). International Evidence on Financial Derivative Usage. Financial Management, 185-206.

Bronzin, V. (1908). Theorie der prämiengeschäfte.

Brown, G., Crabb, P., and Haushalter, D. (2006). Are Firms Successful at Selective Hedging? The Journal of Business, 2925-2949.

Buse, A. (1982). The Likelihood Ratio, Wald, and Lagrange Multiplier Tests: An Expository Note. The American Statistician, 153-157.

Chance, D. (1998). A brief history of derivatives. Essays in Derivatives: Risk-Transfer Tools and Topics Made Easy.

Chanzu, L. N., and Gekara, M. (2014). Effects of use of derivatives on financial performance of companies listed in the Nairobi Security Exchange. International Journal of Academic Research in Accounting, Finance and Management Sciences, 4(4), 27-43.

Choi, J., Mao, C., and Upadhyay, A. (2013). Corporate risk management under information asymmetry. Journal of Business Finance and Accounting, 239-271.

Colquitt, L. L., and Hoyt, R. E. (1997). Determinants of corporate hedging behavior: Evidence from the life insurance industry. Journal of Risk and Insurance, 649-671.

Cummins, J. D., Phillips, R. D., and Smith, S. D. (1997). Corporate hedging in the insurance industry: the use of financial derivatives by US insurers. North American Actuarial Journal, 1, 13-40.

Cummins, J. D., Phillips, R. D., and Smith, S. D. (2001). Derivatives and corporate risk management: participation and volume decisions in the insurance industry. Journal of Risk and Insurance, 68, 51-91. 
De Ceuster, M., Flanagan, L., Hodgson, A., and Tahir, M. I. (2003). Determinants of derivative usage in the life and general insurance industry: The Australian evidence. Review of Pacific Basin Financial Markets and Policies, 6(4), 405-431.

Elango, B., Ma, Y., and Pope, N. (2008). An Investigation Into the Diversification-Performance Relationship in the U.S. Property-Liability Insurance Industry. Journal of Risk and Insurance, 567-591.

Fauver, L., and Naranjo, A. (2010). Derivative usage and firm value: The influence of agency costs and monitoring problems. Journal of corporate finance, 16(5), 719-735.

Graham, J., and Roger, D. (2002). Do firms hedge in response to tax incentives? Journal of Finance, 815-839.

Hardwick, P., and Adams, M. (1999). The determinants of financial derivatives use in the United Kingdom life insurance industry. Abacus, 35(2), 163-184.

Haug, E. G. (2009). The History of Option Pricing and Hedging. In H. W., and Z. H., Vinzenz Bronzin's Option Pricing Models (pp. 471-486). Springer, Berlin, Heidelberg. doi:https://doi.org/10.1007/9783-540-85711-2_23

Lau, C. (2016). How corporate derivatives use impact firm performance? Pacific-Basin Finance Journal, 102-114.

Lee, H., and Lee, C. (2012). An analysis of reinsurance and firm performance: evidence from the Taiwan property-liability insurance industry. The Geneva Papers on Risk and Insurance, 467-484.

Ma, Y., and Elango, B. (2008). When do international operations lead to improved performance? An analysis of property-liability insurers. Risk Management and Insurance Review, 141-155.

Said, A. (2002). Does the Use of Derivatives Impact Bank Performance? A Case Study of Relative Performance during 2002-2009. A case study of relative performance during, 2009, 77-88.

Shapiro, S. S. and Wilk, M. B. (1965) An analysis of variance test for normality (complete samples). Biometrika,52, 591-611.

Shiu, Y.M. (2007). An empirical investigation on derivatives usage: evidence from the United Kingdom general insurance industry. Applied Economics Letters, 14(5), 353-360. doi:10.1080/135.048.50500426319

Shiu, Y. M. (2020). How does reinsurance and derivatives usage affect financial performance? Evidence from the UK non-life insurance industry. Economic Modelling, 88, 376-285. doi:https://doi.org/10.1016/j. econmod.2019.09.048

Tatoğlu, F. Y. (2020). Panel veri ekonometrisi. Beta Yayınevi.

Weisenthal, J. (2012, March 5). The Story Of The First-Ever Options Trade-In Recorded History. Retrieved January 4, 2021, from Business Insider: https://www.businessinsider.com.au/the-story-of-the-firstever-options-trade-in-recorded-history-2012-3

White, H. (1980). A Heteroskedasticity-Consistent Covariance Matrix Estimator and a Direct Test for Heteroskedasticity. Econometrica, 817-838.

Yang, J., Davis, G. C., and Leatham, D. J. (2001). Impact of interest rate swaps on corporate capital structure: an empirical investigation. Applied Financial Economics, 11, 75-81. 